\title{
The vitamin $D$ axis in the lung: a key role for vitamin D-binding protein
}

\author{
L Chishimba, ${ }^{1}$ D R Thickett, ${ }^{2}$ R A Stockley, ${ }^{3}$ A M Wood ${ }^{2}$
}

- Supplementary material including figures is published online only. To view these files please visit the journal online. http://thorax.bmj.com/content/ vol65/issue5

${ }^{1}$ Burton Hospital NHS Trust, Burton-on-Trent, UK ${ }^{2}$ College of Clinical and Experimental Medicine, University of Birmingham, Birmingham, UK

${ }^{3}$ Lung Investigation Unit, University Hospitals Birmingham, Birmingham, UK

\section{Correspondence to} Dr A M Wood, Lung Investigation Unit, University Hospitals Birmingham, Birmingham B15 2TH, UK; a.m.wood@bham.ac.uk

Received 12 October 2009 Accepted 23 December 2009

\section{ABSTRACT}

There has been much recent interest in the role of the vitamin $D$ axis in lung disease, which includes vitamin $D$, vitamin $\mathrm{D}$ receptor (VDR) and vitamin D-binding protein (VDBP; also known as Gc-globulin). VDBP is a serum protein which has immunomodulatory functions relevant in the lung, predominantly relating to macrophage activation and neutrophil chemotaxis. Variations within its gene are also associated with airways disease, implying a role for the protein product in pathogenesis. Thus far the majority of evidence relates to chronic obstructive pulmonary disease (COPD), but is scant in other airways diseases, such as asthma and bronchiectasis. VDBP also acts as a scavenger protein to clear extracellular G-actin released from necrotic cells, which may be of relevance in severe lung infections and acute lung injury. Vitamin $D$ protects against the development of cancer and tuberculosis, although optimal levels are unknown. The majority of circulating vitamin $D$ is bound to VDBP, and its uptake into cells occurs in both bound and unbound forms, which suggests the role of VDBP warrants further study in these conditions as well. This article reviews the evidence of the role VDBP and its gene $(G C)$ in a range of lung diseases, including asthma, COPD and tuberculosis.

\section{INTRODUCTION}

The potential role of vitamin $\mathrm{D}$ in asthma, ${ }^{1}$ chronic obstructive pulmonary disease (COPD) ${ }^{2}$ and tuberculosis $(\mathrm{TB})^{3}$ has recently been highlighted in a series of editorials, and is summarised in table 1. The majority of vitamin $\mathrm{D}$ in the circulation is bound to vitamin D-binding protein (VDBP, also known as Gc-globulin), which has anti-inflammatory and immunomodulatory functions independent of vitamin D carriage. ${ }^{45}$ These roles, together with their relationship to serum vitamin D (25hydroxyvitamin D (25-OHD)) levels, may therefore be important in a range of lung diseases.

The human Gc-globulin was originally identified by Hirschfeld in 1959 as a marker in the $\lambda$-globulin of the human serum by serum electrophoresis. ${ }^{6}$ Initially it was characterised as a group-specific component or Gc-globulin, but its identity as the plasma protein that binds vitamin D was not discovered until $1975,{ }^{7}$ when it gained its current name, vitamin $\mathrm{D}$-binding protein (VDBP). VDBP was then known to transport 25-OHD, the major circulating form of vitamin $\mathrm{D}$, and 1,25dihydroxyvitamin $\mathrm{D}(1,25-\mathrm{OHD})$, the most active vitamin $\mathrm{D}$ metabolite, but over the years it has been appreciated that it has other roles beyond effects of the balance between these two forms on bone metabolism. VDBP is expressed in many tissues, including liver, kidney, gonads and fat. ${ }^{8}$ It is also expressed by neutrophils, ${ }^{10}$ contributes to macrophage activation, ${ }^{4}$ augments monocyte and neutrophil chemotaxis to C5-derived peptides ${ }^{11} 12$ and acts as a scavenger protein to clear extracellular G-actin released from necrotic cells. ${ }^{13-15}$ Any or all of these functions are likely to be relevant in the lung.

\section{The human VDBP gene}

The human vitamin D-binding protein gene $(G C)$ is part of a gene cluster that includes the albumin $(A L B)$ and $\boldsymbol{\alpha}$-fetoprotein (AFP) genes (termed the albumin multigene family) and, like the other genes in the cluster, is robustly expressed in the liver and other tissues. ${ }^{8}$ GC is located on chromosome 4 , is $\sim 42 \mathrm{~kb}$ in size, and is comprised of 13 exons, ${ }^{16}$ one of which is entirely untranslated, and two others only partially translated. ${ }^{17}$ Transcription of the gene is regulated by a liver-enriched transcription factor at binding sites close to $G C$ on chromosome $4 .{ }^{18}$ The location of the gene cluster, relative gene positions and the structure of $G C$ are shown in supplementary figure 1 online. Some genetic terminology is also defined in the supplementary material.

\section{GC polymorphisms}

$G C$ is highly polymorphic, with three commonly recognised variants (GC1F, GC1S and GC2) and $>120$ rarer variants. ${ }^{19}$ Single nucleotide polymorphisms (SNPs; rs4588 and rs7041) in exon 11 of the gene result in the common isoforms, termed GC1 and GC2; GC1 is then subdivided into GC1F and GC1S. Their protein products differ at positions 416 and 420, such that GC1F and GC1S proteins are identical except for a substitution of glutamic acid for aspartic acid in GC1S at position 416, whilst GC2 differs from GC1F by having a further substitution of lysine for threonine at position $420^{20}$ (table 2). These polymorphisms affect protein function, such that GC2 is less able to be converted to macrophage-activating factor, ${ }^{4}$ resulting in reduced macrophage function in $G C 2$ carriers.

There is also significant variation in the ability of these common variants to bind vitamin $\mathrm{D}$, perhaps driven by the rs7041 genotype ${ }^{21}$ which may have an impact on serum 25-OHD levels. This may partly explain racial and geographical differences in $G C$ allele frequencies, ${ }^{22}$ such that those with higher vitamin D binding affinity (such as GC1F) are more common in darker skinned races, and highly sunexposed regions. Serum levels of both 25-OHD and $1,25-\mathrm{OHD}$ vary according to $G C$ genotype, even within racial groups, ${ }^{23}$ and this, or variations in the other protein functions, may account for 
Table 1 Vitamin D and lung disease

\begin{tabular}{|c|c|c|c|}
\hline Disease & Epidemiology & In vitro research & Clinical research \\
\hline Asthma & $\begin{array}{l}\downarrow \text { levels associate with severity } \\
\uparrow \text { maternal concentrations associate with } \\
\text { childhood atopy }\end{array}$ & 1,25-0HD alters Th1-Th2 balance & Supplementation trial under way \\
\hline COPD & $\begin{array}{l}\downarrow \text { levels associate with } \downarrow \mathrm{FEV}_{1} \\
\downarrow \text { levels in half of patients with COPD }\end{array}$ & $\begin{array}{l}\text { 1,25-OHD } \uparrow \text { clearance of Pseudomonas } \\
\text { and Staphyloccus spp }\end{array}$ & Supplementation trial under way \\
\hline TB & $\downarrow$ levels in patients with TB & $1,25-\mathrm{OHD} \uparrow$ clearance of mycobacteria & $\begin{array}{l}1 \text { RCT of supplementation: no benefit } \\
\text { Further trials under way }\end{array}$ \\
\hline Lung cancer & $\begin{array}{l}\downarrow \text { levels associate with cancer incidence } \\
\uparrow \text { levels associate with better response to } \\
\text { treatment }\end{array}$ & $\begin{array}{l}25-\mathrm{OHD} \text { supplements } \downarrow \text { metastasis in } \\
\text { murine models }\end{array}$ & $\begin{array}{l}\text { Supplementation trials under way in } \\
\text { a range of malignancies }\end{array}$ \\
\hline
\end{tabular}

The table summarises some of the existing evidence supporting a role for vitamin $\mathrm{D}$ in lung disease. Original references for these studies can be found in recent editorials/reviews, ${ }^{1-3}$ being omitted here in order to simplify the text in the table.

COPD, chronic obstructive pulmonary disease; FEV ${ }_{1}$, forced expiratory volume in $1 \mathrm{~s}$; 25-OHD, 25-hydroxyvitamin D; 1,25-OHD, 1,25-dihydroxyvitamin $\mathrm{D}$; RCT, randomised controlled trial; TB, tuberculosis; Th, T helper.

associations of the GC genotype with a variety of diseases, including those discussed here. In addition, the response to vitamin D supplementation may relate to GC genotype. ${ }^{24}$ Unlike other VDBP functions, there are no known variations in actin binding capacity as a result of genetic variation. ${ }^{20}$ The role of VDBP in macrophage activation and neutrophil chemotaxis led to studies of genetic associations of $G C$ in lung diseases where such processes might be important in pathogenesis. These will be discussed in disease-specific sections later.

\section{STRUCTURE AND FUNCTION OF VDBP}

VDBP is a glycosylated $\alpha$-globulin, $\sim 58 \mathrm{kDa}$ in size. It is 458 amino acid residues in length and folds into a disulfide-bonded, triple-domain structure, further divided into two repeated, homologous domains of 186 amino acids (domains I and II) and a shorter domain of 86 residues at the C-terminus (domain III) ${ }^{25}$ Its structure is shown in supplementary figure 2 online. In simplified terms, domain I binds vitamin $\mathrm{D}^{25}$ whilst it is predominantly domain III that binds actin, ${ }^{26}$ the functions which are independent of each other.

Circulating vitamin $\mathrm{D}$ and its metabolites are bound to both albumin and VDBP. Since the affinity of albumin for 25-OHD and $1,25-\mathrm{OHD}$ is substantially lower than that of $\mathrm{VDBP}^{27}$ the vast majority are bound to VDBP, but because of its relative abundance a proportion remain bound to albumin. Since the serum levels of both carrier proteins exceed those of 25-OHD and $1,25-\mathrm{OHD}$, the vast majority of these carrier proteins are empty. ${ }^{28}$ The relationship of VDBP and vitamin D concentrations is not yet clear. Low total vitamin $\mathrm{D}$ concentrations were reported in the original VDBP knockout mouse model, but did not relate to that of the active form of vitamin $\mathrm{D}(1,25-\mathrm{OHD})$ in more recent work, ${ }^{29}$ although these concepts have not been studied widely in man.

Vitamin D may be taken up into cells by diffusion of unbound vitamin across cell membranes, and by endocytosis of that bound to VDBP via binding of VDBP to megalin ${ }^{30}$ and cubulin, ${ }^{31}$ a process illustrated in figure 1 . This was first recognised in renal cells, but has now been reported in other tissues, including

Table 2 Haplotypes of rs7041 and rs4588 result in structurally different proteins

\begin{tabular}{lll}
\hline Variant & $\begin{array}{l}\text { Alleles at rs7041 } \\
\text { and rs4588 }\end{array}$ & $\begin{array}{l}\text { Protein composition } \\
\text { at positions } \mathbf{4 1 6} \text { and } \mathbf{4 2 0}\end{array}$ \\
\hline GC1F & G/A & Asp/Thr \\
GC1S & T/A & Glu/Thr \\
GC2 & G/C & Asp/Lys
\end{tabular}

The table shows the alleles present at rs7041 and rs 4588 , and the resulting protein composition at positions 416 and 420 , respectively. macrophages. ${ }^{28}$ These facts have a bearing on reports relating vitamin $\mathrm{D}$ to lung disease, as most assays measure both bound and unbound forms. It is also important to realise that $25-\mathrm{OHD}$ levels must be very low $(<10 \mathrm{ng} / \mathrm{ml})$ before the concentration of $1,25-\mathrm{OHD}$ is affected, due to its regulation by the calcium homeostasis systems. ${ }^{33}$ The serum level of 25-OHD considered normal (or sufficient) is a topic of debate at present, with some reference laboratories known to us using a level of $30 \mathrm{ng} / \mathrm{ml}$, and others $20 \mathrm{ng} / \mathrm{ml}$. Since most of the immunomodulatory function of vitamin $\mathrm{D}$ relates to $1,25-\mathrm{OHD}^{34}$ it may be that only patients exhibiting severe vitamin $\mathrm{D}$ deficiency $(<10 \mathrm{ng} / \mathrm{ml})$ will have any alterations in immune function, since it is only this group in whom 1,25-OHD will also be low. This is likely to be relevant in studies of lung diseases, such as TB, where immune modulation is biologically important.

The ability of VDBP to bind actin blocks the formation of Factin networks that might otherwise occlude the vasculature

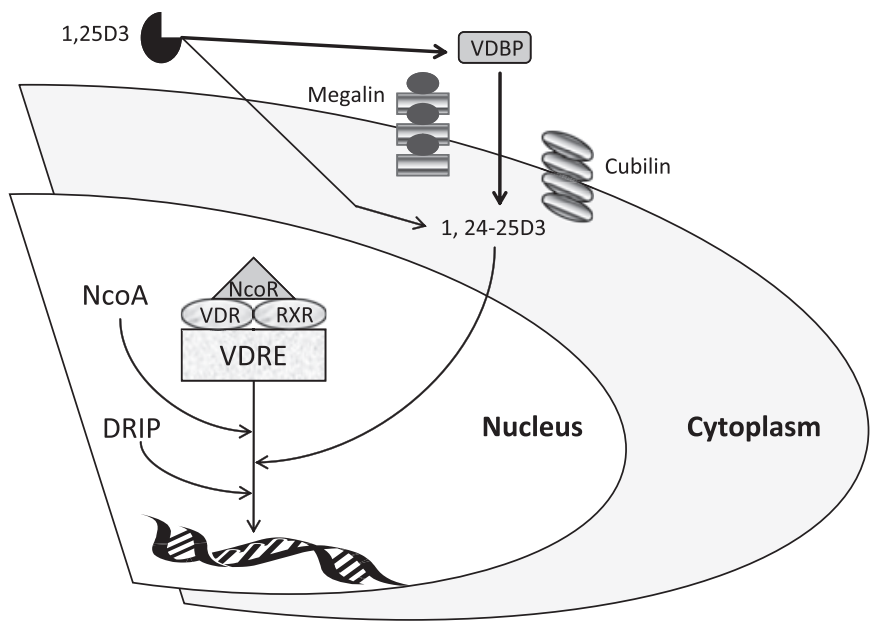

Figure 1 How the vitamin $D$ axis influences cellular response. The diagram shows how vitamin $\mathrm{D}$ and vitamin D-binding protein (VDBP) influence gene transcription via the vitamin $D$ receptor (VDR). Free 1,25hydroxyvitamin $D(1,25-\mathrm{OHD})$ enters cells via diffusion and bound 1,25$\mathrm{OHD}$ by interaction of VDBP with transporter proteins (cubilin and megalin). The metabolite of 1,25-D3 (1,24-25-D3) binds to VDR. VDR is associated with corepressors (NCoR), which dissociate from VDR after ligands (such as 1,24-25-D3) bind. Ligand-bound VDR forms a heterodimer with the retinoid $X$ receptor (RXR) and recruits coactivators (NCoA), resulting in histone acetylation. The resulting VDR complex initiates transcription of accessible DNA templates. The expression of VDR target genes results in cell growth inhibition and synthesis of antimicrobial peptides, such as catheledicin. DRIP, vitamin $D$ receptorinteracting protein; VDRE, vitamin $\mathrm{D}$ receptor response element. Adapted from Ting et al. ${ }^{32}$ 
following cellular damage. The affinity for actin monomers is high $\left(K_{d}=10^{-9} \mathrm{M}\right),{ }^{26}$ and is consistent with actin binding being a major function of VDBP. Since cell death may result in the liberation of large amounts of actin into the extravascular space, and VDBP acts to clear this from the circulation, we might expect VDBP levels to be depressed and actin-VDBP complexes elevated, in any condition where cell death occurs. This hypothesis has been confirmed in a single study of adult respiratory distress syndrome (ARDS), a disease characterised by massive cellular injury. ${ }^{35}$ Low circulating levels of VDBP have also been reported more recently in sepsis. ${ }^{36}$

The other main functions of VDBP relate to macrophage activation $^{4}$ and neutrophil chemotaxis. ${ }^{11}$ VDBP is converted to macrophage-activating factor by the action of either $\beta$-galactosidase from B lymphocytes or sialidase from $\mathrm{T}$ lymphocytes on carbohydrate side chains of the protein. ${ }^{4}$ VDBP is not directly chemotactic to neutrophils, but does enhance the chemotactic effect of complement-derived peptides (C5a), which are able to interact with domain I of VDBP. ${ }^{37}$ CD44 and annexin 2 are thought to play a key role in subsequent interaction of VDBP complexes with neutrophils. ${ }^{38}$ VDBP-binding sites are upregulated on activated neutrophils, ${ }^{39}$ suggesting that changes in its circulating concentration might occur in inflammatory conditions. Consistent with this, in vitro work has shown that GC transcription is enhanced by proinflammatory cytokines. ${ }^{40}$ The functions of VDBP are summarised in table 3.

\section{Location of VDBP}

VDBP is present in various body fluids including serum, peritoneal fluid ${ }^{41}$ and cerebrospinal fluid, ${ }^{42}$ and is also found on the surface of many cell types including human neutrophils. ${ }^{10}$ Although the vast majority of serum VDBP is derived from expression and secretion by liver parenchyma cells, small contributions by non-hepatic cell types including human monocytes are recognised. ${ }^{43}$ This implies widespread functionality of the protein, consistent with its effects on innate immunity and actin binding.

\section{CHRONIC OBSTRUCTIVE PULMONARY DISEASE GC and genetic susceptibility}

Cigarette smoking is the main environmental risk factor for developing COPD, but genetic susceptibility also plays a role in disease of both the airways and the parenchyma. ${ }^{44}$ In addition to the accepted susceptibility conferred by $\alpha$-1-antitrypsin deficiency (AATD) (reviewed elsewhere ${ }^{45}$ ), adequately replicated genetic associations are recognised in candidate genes suggested by the pathogenetic themes of protease-antiprotease imbalance, oxidant-antioxidant imbalance and inflammation. In addition there may be a role for nicotine addiction, given the association between polymorphisms in the $\alpha$-nicotinic acetylcholine receptor locus $(C H R N A 3 / 5)$ and COPD. ${ }^{46}$ The genes or regions associated with COPD in a least one meta-analysis, or in at least two independent populations in genome-wide association (GWA) studies are SERPINE2, ${ }^{47}$ the MMP cluster on chromosome $11,{ }^{48} 49$ the CHRNA3/5 locus, ${ }^{46} H H I P,{ }^{46}{ }^{50}$ the GSTP genes, ${ }^{51}$ IL1B ${ }^{51}$ EPHX $1^{52}$ and TNFA. ${ }^{51}{ }^{53}$ GC has been studied only in smaller COPD populations, and as yet is not the subject of a meta-analysis. Nevertheless it is appropriate to consider current evidence for its role in COPD.

Most studies of GC in COPD (summarised in table 4) have concentrated on known functional variants; such as the GC2 and GC1S alleles, caused by non-synonymous SNPs (rs4588 and rs7041). The relationship between these SNPs, the listed genetic variants and their resultant protein products is shown in table 2. As such it is now recognised that GC2, GC1S and GC1F are not alleles as such, but haplotypes composed of combinations of the SNPs at these loci. We will therefore refer to them as variants from here on. An individual may be homozygous or heterozygous for each variant, depending on the two haplotypes present. The GC1S variant has not been associated with COPD in any racial group. ${ }^{54-56}$ The GC2 variant appears protective in Caucasians. ${ }^{55-57}$ The GC1F variant has been consistently associated with a range of COPD phenotypes in Asian subjects, ${ }^{57-59}$ but results in Caucasians have been inconsistent. ${ }^{556061}$ This is probably because Caucasians have a lower frequency of GC1F, thus the studies were underpowered. A single recent study has reported their results according to SNP genotype rather than the more commonly reported variants; in that work, the rs7041 TT genotype was associated with both low 25-OHD levels and risk of COPD. ${ }^{21}$

An alternative explanation for inconsistency of study results in COPD may be that the true functional variant lies in linkage disequilibrium (LD) with one of the studied variants, or that the phenotype it associates with is very specific, so it is not detectable in heterogeneous populations. With this in mind it is of interest that SNPs adjacent to GC associated with forced expiratory volume in $1 \mathrm{~s}\left(\mathrm{FEV}_{1}\right)$ in a recent GWA study ${ }^{62}$ implying that in an adequately powered study a genetic variant influencing $\mathrm{FEV}_{1}$ can be detected that may well exhibit a degree of LD with GC. Further information pertaining to the strength of LD between these SNPs and the GC2 and GC1F variants may help to ascertain if the reported association could in fact be due to GC variation.

In AATD, which is recognised to exhibit similar genetic associations to usual COPD, we have reported an influence of GC polymorphisms on airway bacterial colonisation and subsequent bronchiectasis. ${ }^{63}$ It is also of note that $G C$ variants have been associated with diffuse panbronchiolitis ${ }^{58}$ (a condition seen almost exclusively in Japan) which leads to bronchiectasis. ${ }^{64}$ This may be due to similar mechanisms to those in COPD and AATD, but will require further study.

Table 3 The functions of vitamin D-binding protein (VDBP)

\begin{tabular}{|c|c|c|}
\hline Function & Relevance to lung and/or systemic disease & Mechanism \\
\hline Vitamin D transportation & $\begin{array}{l}\text { Potential influence of levels of vitamin } D \text { on host } \\
\text { defence and regulation of cell proliferation }\end{array}$ & $\begin{array}{l}\text { Delivery of vitamin D to lung parenchyma and } \\
\text { to alveolar macrophages }\end{array}$ \\
\hline Actin binding & $\begin{array}{l}\text { Prevents systemic vascular occlusion following } \\
\text { cellular damage. Potential relevance in sepsis and } \\
\text { acute lung injury }\end{array}$ & $\begin{array}{l}\text { Prevents formation of F-actin networks in the } \\
\text { systemic circulation }\end{array}$ \\
\hline Neutrophil chemotaxis & $\begin{array}{l}\text { Neutrophilic inflammation is a recognised part of } \\
\text { COPD and ALI pathogenesis. Neutrophil recruitment } \\
\text { is a key part of host defence. }\end{array}$ & Enhances chemotactic effect of complement-derived peptides \\
\hline Macrophage activation & $\begin{array}{l}\text { Macrophage activity is a key part of host defence, } \\
\text { and contributes to COPD and ALI pathogenesis }\end{array}$ & $\begin{array}{l}\text { VDBP is converted to macrophage-activating factor by } \\
\text { enzymes derived from lymphocytes }\end{array}$ \\
\hline
\end{tabular}


Table 4 GC polymorphism and the risk of chronic obstructive pulmonary disease (COPD)

\begin{tabular}{|c|c|c|c|c|c|c|}
\hline Population & & Phenotype & No. of cases/controls & Risk allele & Protective allele & Ref \\
\hline \multirow[t]{5}{*}{ Caucasian } & Canada & COPD & $75 / 64$ & - & GC2 & 61 \\
\hline & Canada & COPD & $104 / 413$ & - & $G C 2$ & 60 \\
\hline & Iceland & $\begin{array}{l}\text { COPD } \\
\text { Chronic bronchitis }\end{array}$ & $\begin{array}{l}112 / 183 \\
48 / 183\end{array}$ & $-\overline{\mathrm{GC}} 1 \mathrm{~F}$ & $\overline{\mathrm{GC} 2}$ & 110 \\
\hline & Russia & COPD & $298 / 237$ & - & - & 56 \\
\hline & USA & COPD & $\begin{array}{l}127 \text { families and } \\
304 / 441\end{array}$ & - & - & 54 \\
\hline \multirow{3}{*}{ Asian } & Japan & $\begin{array}{l}\text { COPD } \\
\text { Rapid decline of } \mathrm{FEV}_{1} \\
\text { Emphysema }\end{array}$ & $\begin{array}{l}113 / 88 \\
86 / 21 \\
85 / 88\end{array}$ & GC1F & - & 57 \\
\hline & Japan & $\begin{array}{l}\text { COPD } \\
\text { Diffuse panbronchiolitis }\end{array}$ & $\begin{array}{l}63 / 82 \\
82 / 82\end{array}$ & GC1F & - & 58 \\
\hline & China & COPD & $69 / 52$ & GC1F & - & 59 \\
\hline
\end{tabular}

The table summarises studies of functional GC variants in COPD phenotypes. Since some of the studies have considered related, albeit different, COPD phenotypes, or have used different severity criteria, meta-analysis has not been performed. There have been three studies in Caucasians reporting that GC2 homozygotes were protected from COPD, but also three negative studies. In Asian subjects there have been four studies reporting GC1F (particularly homozygotes) to be susceptible to COPD, and one report of GC2 acting as a protective variant. It should be noted that the Tatar population in whom this study was performed, whilst ethnically Asian (coming from Mongolia), are relatively heterogeneous in modern Russia, where the study was performed. Ancestral markers to determine racial admixture were not checked, so this population is likely to contain both Asian and Caucasian elements.

$\mathrm{FEV}_{1}$, forced expiratory volume in $1 \mathrm{~s}$

Very little functional work concerning GC polymorphisms has been undertaken in COPD; one study has reported differences in molecular structure which could play a role, ${ }^{65}$ but it is more likely that known differences in conversion to macrophage-activating factor ${ }^{4}$ are important. Differences in neutrophil chemotactic activity between the GC2, GC1F and GC1S proteins have not been found. ${ }^{61}$ Both activated macrophages and neutrophilic inflammation are believed to be important in COPD pathogenesis; since the former is affected by GC variation, this supports a role for the gene in susceptibility.

\section{VDBP}

There has been relatively little work concerning the role of VDBP in COPD, despite the wealth of genetic studies. The protein is present in bronchoalveolar lavage (BAL) fluid from subjects with COPD and asymptomatic smokers. ${ }^{56}$ In general VDBP levels were higher in COPD, ${ }^{5}$ but the effect of smoke exposure is uncertain, as results pertaining to this and VDBP function were inconsistent. It should be noted that since transcription of GC is affected by proinflammatory cytokines, VDBP might be considered an acute phase reactant. As such, differentiation of its role in the lung to ascertain if it is distinct from this will be important. VDBP also interacts with a key mediator of lung damage in COPD-neutrophil elastase (NE) cleaves the VDBP-binding site on neutrophils, such that VDBP is released into the circulation, ${ }^{67}$ where it would become bioactive. Furthermore, the ability of VDBP complexes to mediate neutrophil chemotaxis is prevented by NE inhibitors. ${ }^{67}$ This area warrants further research to clarify its relevance to COPD, and potential for modification by treatment.

\section{TUBERCULOSIS}

\section{GC and genetic susceptibility}

Given that VDBP is involved in both neutrophil chemotaxis and macrophage activation, it is conceivable that airway defence against infection could be altered by GC genotype. Genetic susceptibility to TB has been found in a genome-wide linkage study, ${ }^{68}$ though to date most studies have been relatively small and concentrated on candidate genes relating to immune function. This limits their utility in determining new disease mechanisms but, where associations are well replicated, does not detract from their results. At least one GWA study is now underway, ${ }^{69}$ which has potential to reveal hitherto unrecognised aspects of pathogenesis. Meta-analysis level support for genetic susceptibility exists for SSC11A1 polymorphisms in Asians, ${ }^{70}$ and a non-synonymous SNP in interferon $\gamma$ (IFNG).$^{71}$

If the vitamin $\mathrm{D}$ axis plays a role in TB pathogenesis, ${ }^{3}$ variation within genes such as GC and VDR could be relevant in promoting resistance or susceptibility to the infection. $V D R$ has been more widely studied and genetic variation within it appears to influence lymphocyte response to Mycobacterium tuberculosis. ${ }^{72}$ Nevertheless a meta-analysis of VDR studies was inconclusive, ${ }^{73}$ perhaps due to small study sizes and population heterogeneity. HIV status in particular may influence the apparent effect of susceptibility loci, perhaps because in HIV-positive individuals this surpasses the small risk attributable to genetic factors. ${ }^{74}$ Three studies have reported risk of $\mathrm{TB}$ infection in relation to GC genotype. GC2 homozygotes were more common in TB relative to controls in two studies in Asian populations, ${ }^{75} 76$ but the risk appears to depend on an interaction between vitamin $\mathrm{D}$ status and genotype. ${ }^{76}$ The association might be consistent with their reduced ability to convert GC to macrophage-activating factor, but requires further study of the reasons for synergy with vitamin levels. In Caucasian Russians, no GC genotype was associated with TB. ${ }^{77}$

\section{VDBP and vitamin D}

The main focus of vitamin $\mathrm{D}$ axis research in $\mathrm{TB}$ has been vitamin $\mathrm{D}$ itself. The purpose of this review is to concentrate on other aspects of the axis, so it is appropriate to consider how these relate to vitamin $\mathrm{D}$ concentrations. Circulating vitamin $\mathrm{D}$ levels have often been reported to be low in $\mathrm{TB}$, as summarised elsewhere, ${ }^{3}$ and vitamin $\mathrm{D}$ deficiency has been proposed as part of a mechanism for annual influenza epidemics. ${ }^{78}$ Nevertheless the first trial of supplementation in TB did not improve outcomes $^{79}$ perhaps because vitamin $\mathrm{D}$ concentrations were not improved markedly in the treatment group, or because part of the effect of the vitamin $\mathrm{D}$ axis in $\mathrm{TB}$ lies away from the vitamin. VDBP is elevated in serum during human ${ }^{80}$ and bovine ${ }^{81}$ mycobacterial infections, though it is not known if this relates directly to vitamin D. It is also unclear if VDBP is simply a marker of the acute inflammatory response, since other acute phase reactants were similarly elevated, ${ }^{80}$ or truly reflective of a role for the protein in pathogenesis. Further studies of both 
vitamin $\mathrm{D}$ and VDBP are warranted in infectious lung disease to clarify this.

\section{LUNG CANCER \\ GC and genetic susceptibility}

The vitamin $\mathrm{D}$ endocrine system is involved in a wide variety of biological processes including regulation of cell proliferation and differentiation, and can modulate such processes in cancer cells. ${ }^{82}$ Consequently GC and VDR may both be considered potential candidate genes for malignancy. The literature on genetic susceptibility to malignancy is extensive, and many GWA studies have been carried out already. In lung cancer the most well replicated associations at the GWA level lie in (or close to) CHRNA3/5, ${ }^{83} T E R T^{84}$ and CLPTM1L. ${ }^{84}$ Meta-analysis level support exists for $\mathrm{p} 53^{85}{ }^{85} \mathrm{XPC} \mathrm{C}^{86}$ and hOGG1 (Asians only), ${ }^{87}$ amongst others. Several $V D R$ polymorphisms have recently been associated at meta-analysis level with malignancy, but this was not specific to lung cancer. ${ }^{88}$ No studies have considered GC in lung cancer susceptibility, and studies of the GC1F and GC2 alleles in other malignancies have yielded conflicting results. 8990

\section{VDBP and vitamin D}

Animal and epidemiological studies suggest that active vitamin $\mathrm{D}$ metabolites (such as 1,25-OHD) prevent progression and metastasis of lung cancer. ${ }^{91}{ }^{92}$ Consistent with this, higher rates of total cancer mortality have been reported in regions with less UV-B radiation, where vitamin D levels tend to be lower, ${ }^{92}$ and improved survival has been observed in patients with early-stage non-small cell lung cancer (NSCLC) with high vitamin D levels. ${ }^{93}$ The protective effects of vitamin $\mathrm{D}$ are believed to result from its role as a nuclear transcription factor that regulates cellular mechanisms central to the development of cancer, including cell growth, differentiation and apoptosis. Inhibition of metastasis and angiogenesis seems to be responsible for the anticancer effects of vitamin D in the lung. ${ }^{94}$ It should, however, be noted that although there may be good mechanistic reasons for suggesting that vitamin $\mathrm{D}$ has a direct role in pathogenesis, this has yet to be supported by clinical trial data in lung cancer indicating that supplementation and correction of deficiency is beneficial.

The VDR has also been studied in a murine lung cancer model and is present in both normal lung epithelial cells and those from lung adenomas. ${ }^{95}$ In one study, circulating VDBP levels were similar between subjects with cancer (although not specifically lung cancer) and healthy individuals. ${ }^{96}$ This does not necessarily mean that the vitamin $\mathrm{D}$ axis is not involved in cancer risk. Possible interpretations of the negative result are: (1) the vitamin $\mathrm{D}$ axis has a role local to the tumour site; (2) that the effect is mediated purely by vitamin D and VDR; or (3) VDBP's role is small and difficult to quantify. Current understanding of the role of the vitamin $\mathrm{D}$ axis in malignancy is shown in figure 1 , and would tend to favour the first two of these hypotheses. However, the techniques for measurement of VDBP are now much more sensitive, ${ }^{97}$ such that further study of VDBP in lung cancer should be undertaken to determine any effect. This would be logical follow-up work to proteomic work in a mouse model of lung cancer, which suggested that VDBP acts as a disease biomarker. ${ }^{9}$

\section{ASTHMA}

\section{GC and genetic susceptibility}

In common with COPD, it is recognised that asthma may develop as a consequence of a variety of gene-environment interactions. Genetic associations of asthma have been widely published, and the findings and reproducibility reviewed recently ${ }^{99}$ Briefly, those genes with associations replicated at the GWA level are IL4R, ORMDL3 and IRAK $3,{ }^{99}$ whilst additional meta-analysis level support exists for SNPs within IL4, ${ }^{100}$ TNFA, ${ }^{101}$ GSTM1, ${ }^{102}$ GSTT1, ${ }^{102}$ ADAM $33^{103}$ and ADRB2. ${ }^{104}$ Once again, although genes in the vitamin $\mathrm{D}$ axis have been studied and implicated, they do not have the strongest supporting evidence in the field.

$V D R$ has been more widely studied than GC in asthma, but results have been inconsistent. ${ }^{105-109}$ One small study of GC in asthma did not find an association, although it was probably underpowered to detect a difference. ${ }^{110}$ Overall these results suggest that genes within the vitamin $\mathrm{D}$ axis may be less important in asthma than COPD, perhaps because of the shift towards eosinophilic rather than neutrophilic inflammation.

\section{VDBP and vitamin D}

Murine models of pulmonary eosinophilic inflammation suggest that vitamin D supplementation alters cytokine expression profiles, immunoglobulin $\mathrm{E}$ levels, and the pattern of airway eosinophilia during allergen sensitisation, suggesting that the vitamin $\mathrm{D}$ axis could influence the development of allergy and asthma. ${ }^{111}$ Reports of both low and high 25-OHD levels in relation to asthma can be found in the medical literature, which have been reviewed elsewhere, ${ }^{112}$ though, as before, the relationship of this to the rest of the vitamin $\mathrm{D}$ axis has not been considered in detail. VDBP is also found in the BAL fluid in animal models of asthma, ${ }^{113}$ but there have been no reports comparing VDBP levels of healthy human subjects and those with asthma. The inconsistency of vitamin D studies and the paucity of evidence relating to VDBP mean that no firm conclusions regarding a role in asthma can be made currently.

\section{ACUTE LUNG INJURY}

Acute lung injury is pathologically characterised by diffuse alveolar damage, with neutrophils, macrophages and proteinrich oedema fluid in the alveolar spaces, together with capillary injury, and disruption of the alveolar epithelium. ${ }^{114}$ The involvement of neutrophils and macrophages might support a role for VDBP. However, little supportive evidence of the type seen in the other lung diseases discussed here exists. To date there have been few large studies of genetic susceptibility to acute lung injury, and no genome-wide work or meta-analyses of genetic susceptibility loci. The best replicated associations lie within the candidate genes IL6, ACE and SFTPB, the evidence for this being summarised elsewhere. ${ }^{115}$ No candidate gene studies pertaining to elements of the vitamin $\mathrm{D}$ axis have been published.

Since cell death may result in the liberation of large amounts of actin into the extravascular space, and VDBP acts to clear this from the circulation, we might expect VDBP levels to be depressed and actin-VDBP complexes elevated, in any condition where cell death occurs. This hypothesis has been confirmed in a single study of ARDS, a disease characterised by massive cellular injury. ${ }^{34}$ Low circulating levels of VDBP have also been reported more recently in sepsis. ${ }^{35}$

\section{CONCLUSIONS}

A growing body of research supports the view that vitamin $\mathrm{D}$ and VDBP influence the development of COPD and TB, and that they do so via immunomodulatory effects relating predominantly to macrophage function. Evidence of differences in protein function according to genotype, together with numerous genetic association studies, points to a role for VDBP 
in particular, with recent work suggesting that genotype interacts with vitamin $D$ status to influence risk of disease. Functional work to clarify how VDBP contributes to pulmonary infection and inflammation, and how it relates to serum 25$\mathrm{OHD}$, is now under way and will be a key part of the investigation of the vitamin $\mathrm{D}$ axis, and supplementation of vitamin $\mathrm{D}$ in lung disease.

\section{Competing interests None.}

Provenance and peer review Not commissioned; externally peer reviewed.

\section{REFERENCES}

1. Devereux G, Macdonald H, Hawrylowicz C. Vitamin D and asthma: time for intervention? Am J Respir Crit Care Med 2009;179:739-40.

2. Janssens $\mathbf{W}$, Lehouck $A$, Carremans $C$, et al. Vitamin $D$ beyond bones in chronic obstructive pulmonary disease: time to act. Am J Respir Crit Care Med 2009;179:630-6.

3. Wilkinson RJ, Lange $C$. Vitamin $D$ and tuberculosis: new light on a potent biologic therapy? Am J Respir Crit Care Med 2009;179:740-2.

4. Yamamoto $\mathbf{N}$, Homma S. Vitamin D3 binding protein (group-specific component) is a precursor for the macrophage-activating signal factor from lysophosphatidylcholine-treated lymphocytes. Proc Natl Acad Sci USA 1991;88:8539-43.

5. Metcalf JP, Thompson AB, Gossman GL, et al. Gcglobulin functions as a cochemotaxin in the lower respiratory tract. A potential mechanism for lung neutrophil recruitment in cigarette smokers. Am Rev Respir Dis 1991;143:844-9.

6. Hirschfeld J. Immune-electrophoretic demonstration of qualitative differences in human sera and their relation to the haptoglobins. Acta Pathol Microbiol Scand 1959;47:160-8.

7. Daiger SP, Schanfield MS, Cavalli-Sforza LL. Group-specific component (Gc) proteins bind vitamin D and 25-hydroxyvitamin D. Proc Natl Acad Sci USA 1975;72:2076-80.

8. McLeod JF, Cooke NE. The vitamin D-binding protein, alpha-fetoprotein, albumin multigene family: detection of transcripts in multiple tissues. J Biol Chem 1989;264:21760-9

9. DiMartino SJ, Kew RR. Initial characterization of the vitamin D binding protein (Gcglobulin) binding site on the neutrophil plasma membrane: evidence for a chondroitin sulfate proteoglycan. J Immunol 1999;163:2135-42.

10. Kew RR, Sibug MA, Liuzzo JP, et al. Localization and quantitation of the vitamin D binding protein (Gc-globulin) in human neutrophils. Blood 1993;82:274-83.

11. Binder R, Kress A, Kan G, et al. Neutrophil priming by cytokines and vitamin D binding protein (Gc-globulin): impact on C5a-mediated chemotaxis, degranulation and respiratory burst. Mol Immunol 1999;36:885-92.

12. Piquette CA, Robinson-Hill R, Webster RO. Human monocyte chemotaxis to complement-derived chemotaxins is enhanced by Gc-globulin. J Leukoc Biol 1994;55:349-54.

13. Haddad JG, Hu YZ, Kowalski MA, et al. Identification of the sterol- and actinbinding domains of plasma vitamin D binding protein (Gc-globulin). Biochemistry 1992; 31:7174-81.

14. Mc Leod JF, Kowalski MA, Haddad JG Jr. Interactions among serum vitamin D binding protein, monomeric actin, profilin, and profilactin. J Biol Chem 1989;264:1260-7.

15. Janmey PA, Stossel TP, Lind SE. Sequential binding of actin monomers to plasma gelsolin and its inhibition by vitamin D-binding protein. Biochem Biophys Res Commun 1986;136:72-9.

16. Cooke NE, Willard HF, David EV, et al. Direct regional assignment of the gene for vitamin D binding protein (Gc-globulin) to human chromosome $4 q 11-q 13$ and identification of an associated DNA polymorphism. Hum Genet 1986;73:225-9.

17. Witke WF, Gibbs PE, Zielinski R, et al. Complete structure of the human Gc gene: differences and similarities between members of the albumin gene family. Genomics 1993;16:751-4.

18. Hiroki T, Liebhaber SA, Cooke NE. An intronic locus control region plays an essential role in the establishment of an autonomous hepatic chromatin domain for the human vitamin D-binding protein gene. Mol Cell Biol 2007;27:7365-80.

19. Cleve H, Constans J. The mutants of the vitamin-D-binding protein: more than 120 variants of the GC/DBP system. Vox Sang 1988;54:215-25.

20. Speeckaert M, Huang G, Delanghe JR, et al. Biological and clinical aspects of the vitamin D binding protein (Gc-globulin) and its polymorphism. Clin Chim Acta 2006;372:33-42.

21. Janssens $\mathbf{W}$, Bouillon $\mathrm{R}$, Claes $\mathrm{B}$, et al. Vitamin $\mathrm{D}$ deficiency is highly prevalent in COPD and correlates with variants in the vitamin D binding gene. Thorax. Published online first: 8 December 2009. doi:10.1136/thx.2009.120659

22. Kamboh MI, Ferrell RE. Ethnic variation in vitamin D-binding protein (GC): a review of isoelectric focusing studies in human populations. Hum Genet 1986;72:281-93.

23. Engelman CD, Fingerlin TE, Langefeld CD, et al. Genetic and environmental determinants of 25-hydroxyvitamin D and 1,25-dihydroxyvitamin D levels in Hispanic and African Americans. J Clin Endocrinol Metab 2008;93:3381-8.

24. Fu L, Yun F, Oczak M, et al. Common genetic variants of the vitamin D binding protein (DBP) predict differences in response of serum 25-hydroxyvitamin D [25(OH) D] to vitamin D supplementation. Clin Biochem 2009;42:1174-7.
25. Swamy N, Head JF, Weitz D, et al. Biochemical and preliminary crystallographic characterization of the vitamin $\mathrm{D}$ sterol- and actin-binding by human vitamin D-binding protein. Arch Biochem Biophys 2002;402:14-23.

26. Goldschmidt-Clermont PJ, Van Alstyne EL, Day JR, et al. Group-specific component (vitamin $\mathrm{D}$ binding protein) prevents the interaction between $\mathrm{G}$-actin and profilin. Biochemistry 1986;25:6467-72.

27. Bikle DD, Siiteri PK, Ryzen E, et al. Serum protein binding of 1,25-dihydroxyvitamin $\mathrm{D}$ : a reevaluation by direct measurement of free metabolite levels. J Clin Endocrinol Metab 1985:61:969-75.

28. Chun RF, Adams JS, Hewison M. Back to the future: a new look at 'old' vitamin D. $\checkmark$ Endocrinol 2008;198:261-9.

29. Zella LA, Shevde NK, Hollis BW, et al. Vitamin D-binding protein influences total circulating levels of 1,25-dihydroxyvitamin D3 but does not directly modulate the bioactive levels of the hormone in vivo. Endocrinology 2008;149:3656-67.

30. Nykjaer A, Dragun D, Walther D, et al. An endocytic pathway essential for renal uptake and activation of the steroid $25-(\mathrm{OH})$ vitamin D3. Cell 1999:96:507-15.

31. Nykjaer A, Fyfe JC, Kozyraki R, et al. Cubilin dysfunction causes abnormal metabolism of the steroid hormone $25(\mathrm{OH})$ vitamin D(3). Proc Natl Acad Sci USA 2001:98:13895-900.

32. Ting $\mathbf{H J}, \mathrm{Bao} B Y$, Reeder JE, et al. Increased expression of corepressors in aggressive androgen-independent prostate cancer cells results in loss of 1alpha,25-dihydroxyvitamin D3 responsiveness. Mol Cancer Res 2007:5:967-80.

33. Need AG, O'Loughlin PD, Morris HA, et al. Vitamin D metabolites and calcium absorption in severe vitamin D deficiency. J Bone Miner Res 2008;23:1859-63.

34. Adams JS, Hewison M. Unexpected actions of vitamin D: new perspectives on the regulation of innate and adaptive immunity. Nat Clin Pract Endocrinol Metab 2008; 4:80-90.

35. Lind SE, Smith DB, Janmey PA, et al. Depression of gelsolin levels and detection of gelsolin-actin complexes in plasma of patients with acute lung injury. Am Rev Respir Dis 1988;138:429-34

36. Jeng L, Yamshchikov AV, Judd SE, et al. Alterations in vitamin D status and antimicrobial peptide levels in patients in the intensive care unit with sepsis. J Trans/ Med 2009;7:28.

37. Zhang J, Kew RR. Identification of a region in the vitamin D-binding protein that mediates its C5a chemotactic cofactor function. J Biol Chem 2004;279:53282-7.

38. McVoy LA, Kew RR. CD44 and annexin A2 mediate the C5a chemotactic cofactor function of the vitamin D binding protein. J Immunol 2005;175:4754-60.

39. DiMartino SJ, Trujillo G, McVoy LA, et al. Upregulation of vitamin D binding protein (Gc-globulin) binding sites during neutrophil activation from a latent reservoir in azurophil granules. Mol Immunol 2007;44:2370-7.

40. Guha C, Osawa M, Werner PA, et al. Regulation of human Gc (vitamin D-binding) protein levels: hormonal and cytokine control of gene expression in vitro. Hepatology 1995;21:1675-81.

41. Delmez JA, Slatopolsky E, Martin KJ, et al. Minerals, vitamin D, and parathyroid hormone in continuous ambulatory peritoneal dialysis. Kidney Int 1982;21:862-7.

42. Katikaneni LP, Emerson DL, Goldschmidt-Clermont PJ, et al. High levels of groupspecific component (vitamin-D-binding protein) in the cerebrospinal fluid of infants aged less than 2 months. Biol Neonate 1987;52:250-5.

43. Sabbatini A, Petrini M, Mattii L, et al. Vitamin D binding protein is produced by human monocytes. FEBS Lett 1993;323:89-92.

44. Patel BD, Coxson HO, Pillai SG, et al. Airway wall thickening and emphysema show independent familial aggregation in chronic obstructive pulmonary disease. Am J Respir Crit Care Med 2008;178:500-5.

45. Wood AM, Stockley RA. Alpha one antitrypsin deficiency: from gene to treatment. Respiration 2007;74:481-92.

46. Pillai SG, Ge D, Zhu G, et al. A genome-wide association study in chronic obstructive pulmonary disease (COPD): identification of two major susceptibility loci. PLoS Genet 2009;5:e1000421.

47. Zhu G, Warren L, Aponte J, et al. The SERPINE2 gene is associated with chronic obstructive pulmonary disease in two large populations. Am J Respir Crit Care Med 2007; 176:167-73.

48. Demeo DL, Hersh CP, Hoffman EA, et al. Genetic determinants of emphysema distribution in the national emphysema treatment trial. Am J Respir Crit Care Med 2007;176:42-8

49. Kong $\mathbf{X}$, Coxson HO, Lomas DA, et al. Genome-wide association of high resolution CT phenotypes in two independent COPD populations. San Diego: American Thoracic Society. Am J Respir Crit Care Med 2009;179:A2444.

50. Wilk JB, Chen TH, Gottlieb DJ, et al. A genome-wide association study of pulmonary function measures in the Framingham Heart Study. PLoS Genet 2009;5 e1000429.

51. Smolonska J, Wijmenga C, Postma DS, et al. Meta-analyses on suspected COPD genes-a summary of 20 years' research. Am J Respir Crit Care Med 2009 180:618-31.

52. Hu G, Shi Z, Hu J, et al. Association between polymorphisms of microsomal epoxide hydrolase and COPD: results from meta-analyses. Respirology 2008:13:837-50.

53. Gingo MR, Silveira LJ, Miller YE, et al. Tumour necrosis factor gene polymorphisms are associated with COPD. Eur Respir J 2008;31:1005-12

54. Hersh CP, Demeo DL, Lange C, et al. Attempted replication of reported chronic obstructive pulmonary disease candidate gene associations. Am J Respir Cell Mol Biol 2005;33:71-8. 
55. Sandford AJ, Chagani T, Weir TD, et al. Susceptibility genes for rapid decline of lung function in the lung health study. Am J Respir Crit Care Med 2001;163:469-73.

56. Korytina GF, Akhmadishina LZ, lanbaeva DG, et al. [Genotypes of vitamin-D-binding protein (DBP) in patients with chronic obstructive pulmonary disease and healthy population of Republic Bashkortostan] (In Russian.). Mol Biol (Mosk) 2006:40:231-8.

57. Ito I, Nagai S, Hoshino $Y$, et al. Risk and severity of COPD is associated with the group-specific component of serum globulin $1 \mathrm{~F}$ allele. Chest 2004:125:63-70.

58. Ishii T, Keicho N, Teramoto S, et al. Association of Gc-globulin variation with susceptibility to COPD and diffuse panbronchiolitis. Eur Respir J 2001;18:753-7.

59. Lu M, Yang B, Cai YY. [The relationship between vitamin D binding protein gene polymorphism and chronic obstructive pulmonary disease] (In Chinese.). Zhonghua Nei Ke Za Zhi 2004;43:117-20.

60. Horne SL, Cockcroft DW, Dosman JA. Possible protective effect against chronic obstructive airways disease by the GC2 allele. Hum Hered 1990;40:173-6.

61. Schellenberg D, Pare PD, Weir TD, et al. Vitamin D binding protein variants and the risk of COPD. Am J Respir Crit Care Med 1998;157:957-61.

62. Wilk JB, Walter RE, Laramie JM, et al. Framingham Heart Study genome-wide association: results for pulmonary function measures. BMC Med Genet 2007:8 Suppl 1;:S8

63. Wood AM, Simmonds MJ, Newby PR, et al. Variation in the vitamin D binding protein gene is associated with the development of bronchiectasis in AATD. Toronto: American Thoracic Society: Am J Respir Crit Care Med 2008;178:A776

64. Poletti V, Casoni G, Chilosi M, et al. Diffuse panbronchiolitis. Eur Respir J 2006:28:862-71.

65. Ohkura K, Nagasawa $\mathrm{H}$, Uto $\mathrm{Y}$, et al. The role of Gc protein oligosaccharide structure as a risk factor for COPD. Anticancer Res 2006;26:4073-8.

66. Robbins RA, Gossman GL, Nelson KJ, et al. Inactivation of chemotactic factor inactivator by cigarette smoke. A potential mechanism of modulating neutrophil recruitment to the lung. Am Rev Respir Dis 1990:142:763-8.

67. DiMartino SJ, Shah AB, Trujillo $G$, et al. Elastase controls the binding of the vitamin D-binding protein (Gc-globulin) to neutrophils: a potential role in the regulation of C5a co-chemotactic activity. J Immunol 2001;166:2688-94.

68. Bellamy R, Beyers N, McAdam KP, et al. Genetic susceptibility to tuberculosis in Africans: a genome-wide scan. Proc Natl Acad Sci USA 2000;97:8005-9.

69. Smith I, Nathan C, Peavy HH. Progress and new directions in genetics of tuberculosis: an NHLBI working group report. Am J Respir Crit Care Med 2005:172:1491-6.

70. Li HT, Zhang TT, Zhou Y0, et al. SLC11A1 (formerly NRAMP1) gene polymorphisms and tuberculosis susceptibility: a meta-analysis. Int J Tuberc Lung Dis 2006;10:3-12.

71. Pacheco AG, Cardoso CC, Moraes MO. IFNG +874T/A, IL10 -1082G/A and TNF $-308 \mathrm{G} / \mathrm{A}$ polymorphisms in association with tuberculosis susceptibility: a metaanalysis study. Hum Genet 2008;123:477-84.

72. Selvaraj $\mathbf{P}$, Kurian SM, Uma H, et al. Influence of non-MHC genes on lymphocyte response to Mycobacterium tuberculosis antigens \& tuberculin reactive status in pulmonary tuberculosis. Indian J Med Res 2000;112:86-92.

73. Lewis SJ, Baker I, Davey Smith G. Meta-analysis of vitamin D receptor polymorphisms and pulmonary tuberculosis risk. Int J Tuberc Lung Dis 2005;9:1174-7.

74. Soborg C, Andersen AB, Range N, et al. Influence of candidate susceptibility genes on tuberculosis in a high endemic region. Mol Immunol 2007:44:2213-20.

75. Papiha SS, White I, Roberts DF. Some genetic implications of isoelectric focusing of human red cell phosphoglucomutase (PGM1) and serum protein group specific component (Gc): genetic diversity in the populations of Himachal Pradesh, India. Hum Genet 1983;63:67-72.

76. Martineau AR, Leandro AC, Anderson ST, et al. Association between Gc genotype and susceptibility to TB is dependent on vitamin D status. Eur Respir J. Published online first: 24 September 2009.

77. Spitsyn VA, Titenko NV. [Subtypes of serum group specific component (Gc) in normal conditions and in pathology]. Genetika 1990;26:749-59.

78. Cannell JJ, Vieth R, Umhau JC, et al. Epidemic influenza and vitamin D. Epidemiol Infect 2006:134:1129-40.

79. Wejse C, Gomes VF, Rabna P, et al. Vitamin D as supplementary treatment for tuberculosis: a double-blind, randomized, placebo-controlled trial. Am J Respir Crit Care Med 2009;179:843-50.

80. Emmett M, Miller JL, Crowle AJ. Protein abnormalities in adult respiratory distress syndrome, tuberculosis, and cystic fibrosis sera. Proc Soc Exp Biol Med 1987; 184:74-82

81. Seth $\mathbf{M}$, Lamont EA, Janagama HK, et al. Biomarker discovery in subclinical mycobacterial infections of cattle. PLoS One 2009:4:e5478.

82. Giovannucci $\mathbf{E}$. The epidemiology of vitamin $D$ and cancer incidence and mortality: a review (United States). Cancer Causes Control 2005:16:83-95.

83. Hung RJ, McKay JD, Gaborieau V, et al. A susceptibility locus for lung cancer maps to nicotinic acetylcholine receptor subunit genes on 15q25. Nature 2008;452:633-7.

84. McKay JD, Hung RJ, Gaborieau V, et al. Lung cancer susceptibility locus at 5p15.33. Nat Genet 2008:40:1404-6.

85. Dai S, Mao C, Jiang L, et al. P53 polymorphism and lung cancer susceptibility: a pooled analysis of 32 case-control studies. Hum Genet 2009:125:633-8.

86. Oiu L, Wang Z, Shi X. Associations between XPC polymorphisms and risk of cancers: a meta-analysis. Eur J Cancer 2008;44:2241-53.
87. Li H, Hao X, Zhang W, et al. The hOGG1 Ser326Cys polymorphism and lung cancer risk: a meta-analysis. Cancer Epidemiol Biomarkers Prev 2008;17:1739-45.

88. Raimondi S, Johansson $\mathrm{H}$, Maisonneuve $\mathrm{P}$, et al. Review and meta-analysis on vitamin $D$ receptor polymorphisms and cancer risk. Carcinogenesis 2009;30:1170-80

89. Abbas S, Linseisen J, Slanger T, et al. The Gc2 allele of the vitamin D binding protein is associated with a decreased postmenopausal breast cancer risk independent of the vitamin D status. Cancer Epidemiol Biomarkers Prev 2008;17:1339-43.

90. McCullough ML, Stevens VL, Diver WR, et al. Vitamin D pathway gene polymorphisms, diet, and risk of postmenopausal breast cancer: a nested casecontrol study. Breast Cancer Res 2007:9:R9.

91. Nakagawa K, Kawaura A, Kato S, et al. 1 alpha,25-Dihydroxyvitamin $D(3)$ is a preventive factor in the metastasis of lung cancer. Carcinogenesis 2005:26:429-40.

92. Porojnicu AC, Robsahm TE, Dahlback A, et al. Seasonal and geographical variations in lung cancer prognosis in Norway. Does vitamin $D$ from the sun play a role? Lung Cancer 2007;55:263-70.

93. Zhou W, Heist RS, Liu G, et al. Circulating 25-hydroxyvitamin D levels predict survival in early-stage non-small-cell lung cancer patients. J Clin Oncol 2007;25:479-85.

94. Nakagawa K, Sasaki Y, Kato S, et al. 22-0xa-1alpha,25-dihydroxyvitamin D3 inhibits metastasis and angiogenesis in lung cancer. Carcinogenesis 2005;26:1044-54

95. Zhong K, Chua BH, Palmer KC. Vitamin D3 receptor expression in $\mathrm{N}$-ethylnitrosourea-induced mouse pulmonary adenomas. Am J Respir Cell Mol Biol 1994;11:480-6.

96. Rostenberg I, Rico R, Penaloza R. Gc globulin and prealbumin serum levels in patients with cancer and benign inflammatory diseases and in asymptomatic smokers. J Nat/ Cancer Inst 1979;62:299-300.

97. Jorgensen CS, Christiansen M, Norgaard-Pedersen B, et al. Gc globulin (vitamin D-binding protein) levels: an inhibition ELISA assay for determination of the total concentration of Gc globulin in plasma and serum. Scand J Clin Lab Invest 2004:64:157-66.

98. Chatterji B, Borlak J. Serum proteomics of lung adenocarcinomas induced by targeted overexpression of c-raf in alveolar epithelium identifies candidate biomarkers. Proteomics 2007;7:3980-91.

99. Rogers AJ, Raby BA, Lasky-Su JA, et al. Assessing the reproducibility of asthma candidate gene associations, using genome-wide data. Am J Respir Crit Care Med 2009;179:1084-90.

100. Li Y, Guo B, Zhang L, et al. Association between C-589T polymorphisms of interleukin-4 gene promoter and asthma: a meta-analysis. Respir Med 2008; 102:984-92

101. Gao J, Shan G, Sun B, et al. Association between polymorphism of tumour necrosis factor alpha-308 gene promoter and asthma: a meta-analysis. Thorax 2006;61:466-71.

102. Saadat M, Ansari-Lari M. Genetic polymorphism of glutathione S-transferase T1, M1 and asthma, a meta-analysis of the literature. Pak J Biol Sci 2007;10:4183-9.

103. Blakey J, Halapi E, Bjornsdottir US, et al. Contribution of ADAM33 polymorphisms to the population risk of asthma. Thorax 2005;60:274-6.

104. Thakkinstian A, McEvoy M, Minelli C, et al. Systematic review and meta-analysis of the association between \{beta\}2-adrenoceptor polymorphisms and asthma: a HuGE review. Am J Epidemiol 2005;162:201-11.

105. Poon AH, Laprise C, Lemire M, et al. Association of vitamin D receptor genetic variants with susceptibility to asthma and atopy. Am J Respir Crit Care Med 2004:170:967-73

106. Raby BA, Lazarus $R$, Silverman EK, et al. Association of vitamin D receptor gene polymorphisms with childhood and adult asthma. Am J Respir Crit Care Med 2004:170:1057-65

107. Vollmert C, Illig T, Altmuller J, et al. Single nucleotide polymorphism screening and association analysis - exclusion of integrin beta 7 and vitamin $D$ receptor (chromosome 12q) as candidate genes for asthma. Clin Exp Allergy 2004:34:1841-50.

108. Wjst M. Variants in the vitamin D receptor gene and asthma. BMC Genet 2005;6:2

109. Gao B, Hu J, Stricker $\mathrm{S}$, et al. A mutation in Ihh that causes digit abnormalities alters its signalling capacity and range. Nature 2009;458:1196-200.

110. Laufs J, Andrason H, Sigvaldason A, et al. Association of vitamin D binding protein variants with chronic mucus hypersecretion in Iceland. Am J Pharmacogenomics 2004:4:63-8.

111. Matheu V, Back O, Mondoc E, et al. Dual effects of vitamin D-induced alteration of TH1/TH2 cytokine expression: enhancing lgE production and decreasing airway eosinophilia in murine allergic airway disease. J Allergy Clin Immunol 2003; 112:585-92.

112. Litonjua AA. Childhood asthma may be a consequence of vitamin $\mathrm{D}$ deficiency. Curr Opin Allergy Clin Immunol 2009:9:202-7.

113. Zhao J, Yeong LH, Wong WS. Dexamethasone alters bronchoalveolar lavage fluid proteome in a mouse asthma model. Int Arch Allergy Immunol 2007:142:219-29.

114. Wheeler AP, Bernard GR. Acute lung injury and the acute respiratory distress syndrome: a clinical review. Lancet 2007:369:1553-64.

115. Gao L, Barnes KC. Recent advances in genetic predisposition to clinical acute lung injury. Am J Physiol Lung Cell Mol Physiol 2009;296:L713-25. 